\title{
CORRIGENDUM
}

\section{Mycobacterium tuberculosis nitrogen assimilation and host colonization require aspartate}

Alexandre Gouzy, Gérald Larrouy-Maumus, Ting-Di Wu, Antonio Peixoto, Florence Levillain, Geanncarlo Lugo-Villarino, Jean-Luc Gerquin-Kern, Luiz Pedro Sório de Carvalho, Yannick Poquet \& Olivier Neyrolles

Nat. Chem. Biol. 9, 674-676 (2013); published online 29 September 2013; corrected after print 11 December 2013

In the version of this article initially published, the name of contributing author Jean-Luc Guerquin-Kern was misspelled as Jean-Luc Gerquin-Kern. The error has been corrected in the HTML and PDF versions of the article.

\section{CORRIGENDUM}

\section{Elementary tetrahelical protein design for diverse oxidoreductase functions}

Tammer A Farid, Goutham Kodali, Lee A Solomon, Bruce R Lichtenstein, Molly M Sheehan, Bryan A Fry, Chris Bialas, Nathan M Ennist, Jessica A Siedlecki, Zhenyu Zhao, Matthew A Stetz, Kathleen G Valentine, J L Ross Anderson, A Joshua Wand, Bohdana M Discher, Christopher C Moser \& P Leslie Dutton

Nat. Chem. Biol. 9, 826-833 (2013); published online 13 October 2013; corrected after print 11 December 2013

In the version of this article initially published, the US Department of Energy Office of Basic Energy Sciences, Energy Frontier Research Center grant number was incorrect. The correct number is DE-SC 0001035. The error has been corrected in the HTML and PDF versions of the article.

\section{ERRATUM}

\section{What's up 'Doc'?}

Wolfgang Peti \& Rebecca Page

Nat. Chem. Biol. 9, 756-757 (2013); published online 20 October 2013; corrected after print 11 December 2013

In the version of this article initially published, the citation to reference 4 incorrectly referred to "Castro-Roa, K.. The correct author's name is "Castro-Roa, D.". The error has been corrected in the HTML and PDF versions of the article.

\section{CORRIGENDUM}

\section{A serine-substituted P450 catalyzes highly efficient carbene transfer to olefins in vivo}

Pedro S Coelho, Z Jane Wang, Maraia E Ener, Stefanie A Baril, Arvind Kannan, Frances H Arnold \& Eric M Brustad

Nat. Chem. Biol. 9, 485-487 (2013); published online 23 June 2013; corrected after print 19 December 2013

In the version of this article initially published, the Protein Data Bank codes for the P450 and P411 constructs were inadvertently switched. Accession code $4 \mathrm{H} 23$ actually corresponds to the P411 structure, and $4 \mathrm{H} 24$ corresponds to the P450 structure. The error has been corrected in the HTML and PDF versions of the article. 